\title{
WILLIAM B. ALLISON AND THE PRESIDENCY IN 1888.
}

From "Four National Conventions," by Hon. Geo. F. Hoar, in Scribner'a Magazine for February, 1899.

After several ineffectual ballotings, in which the votes of the different states were divided among several candidates, the convention took a recess at twelve o'clock to four o'clock of the same day. Immediately a meeting was called by a number of gentlemen representing different delegations, in a room in the building where the convention was held, for consultation, and to see if they could agree upon a candidate. The Massachusetts delegation had authorized me to cast their vote as a unit for any candidate for whom I should tbink best, whom sixteen of the delegates-being one more than a majority-approved. I had ascertained their opinion. While as I said there were but thirteen at most who would support Sherman, considerably more than sixteen were willing to support either Harrison or Allison, and perhaps one or two others who had been prominently mentioned, including, I think Mr. Depew, although of that I am not certain. We met as I saicl. The New York delegation had authorized its vote to be cast unanimously for any person on whom the four delegates at large, Platt, Miller, Depew and Hiscock, representing different shades of opinion in the Republican party of that state, should agree. Three of these gentlemen, Platt, Miller and Hiscock, were present at the meeting. Mr. Quay, chairman of the Pennsylvania delegation, was also authorized to cast the vote of the entire delegation as he should think fit. Mr. Spooner, of Wisconsin, chairman of the Wisconsin delegation, was present with a like authority. Mr. Farwell, chairman of the Illinois delegation, was present with a like authority from his state. Mr. Clarkson, chairman of the Iowa delegation, was present with authority to vote for $\mathrm{Mr}$. Allison from the begimning. DeYoung, of California, thought he could speak for his people, though, I believe, 
without claiming authority from them. Filley, of Missouri, was also present. There were several other gentlemen of influence, though not all of them delegates, and not all of them entitled. to speak for their states, but feeling able to assure the company that their states would accede to whatever agreement might be made there. The names of several candidates were discussed. I made a very earnest speech in favor of Mr. Allison, setting forth what I thought were the qualities that would make him a popular candidate, and would make him an able and a wise President.

Finally, all agreed that their states should vote for $\mathrm{Mr}$. Allison, when the convention came in at six o'clock. Depew, as I have said, was absent. But his three colleagues said there could be no doubt that he would agree to their action, and there would be no difficulty about New York: We thought it best, as a matter of | precaution, to meet again a half-hour before the coming in of the convention, to be sure the thing was to go through all right. I suppose that everybody in that room when he left it felt as certain as of any event in the future that $\mathrm{Mr}$. Allison would be nominated in the convention.

But when we met at the time fixed, the three delegates at large from New York said they were sorry they could not carry out their engagement. Mr. Depew, who had been supported as a candidate by his state, in the earlier ballots, had made a speech withdrawing his name. But when the action of the meeting was reported to him, he said he had been compelled to withdraw by the opposition of the agrarian element, which was hostile to railroads. He was then president of the New York Central \& Hudson River Railroad Company. He said that this opposition to him came largely from Iowa, and from the Northwest, where was found the chief support of Mr. Allison; that while he had withdrawn his own name, he would not so far submit to such an unreasonable and socialistic sentiment as to give his consent that it should dictate a candidate for the Republican party. The 
three other delegates at large were therefore compelled to refuse their support to the arrangement which had been conditionally agreed on, and the thing fell through. If it had gone on, New York, Illinois, Wisconsin, Pennsylvania, Massachusetts, Iowa, California, and perhaps Missouri, would have cast their votes unanimously for Allison, and his nomination would have been sure. I think no other person ever came so near the presidency of the United States, and missed it. . . . The result was the nomination of Mr. Harrison.

The Clmate.-Since last July, there has scarcely been enough rain to keep vegetation from being parched up completely. Throughout the Fall and Winter thus far, it may be said that a drouth has rested upon the country. On the first of January a little rain fell-sufficient to make it quite muddy and on the second it changed to snow, which fell to. the depth of six or eight inches in this place, but was much. deeper north and west. At Iowa City, the snow was nearly; twice as deep as here-enough to make sleighing of the most superb quality. The sleighing lasted just one month.. The climate of Iowa must ever be subject to less rain than: almost any other portion of the west-lying, as it does, far. from the influence of the Great Lakes, and having no range. of mountains or highlands to operate as condensers to the rarefied and ascending vapors; the natural laws of evaporation will exhaust the moisture from her soil and bear it away to some cooler state of the atmosphere. It is only when a long continued heat shall operate to rarefy the air to an excess sufficient to produce a rapid circulation approaching to. a storm, that we can reasonably expect rain. In this latter event the cooler vapors are forced into the vacuum, and if collected in sufficient quantities, fall of course, to the earth. -Bloomington (Muscatine) Herald, February 26, 1847.

Vou. IV. -15 
Copyright of Annals of Iowa is the property of State of Iowa, by \& through the State Historical Society of Iowa and its content may not be copied or emailed to multiple sites or posted to a listserv without the copyright holder's express written permission. However, users may print, download, or email articles for individual use. 